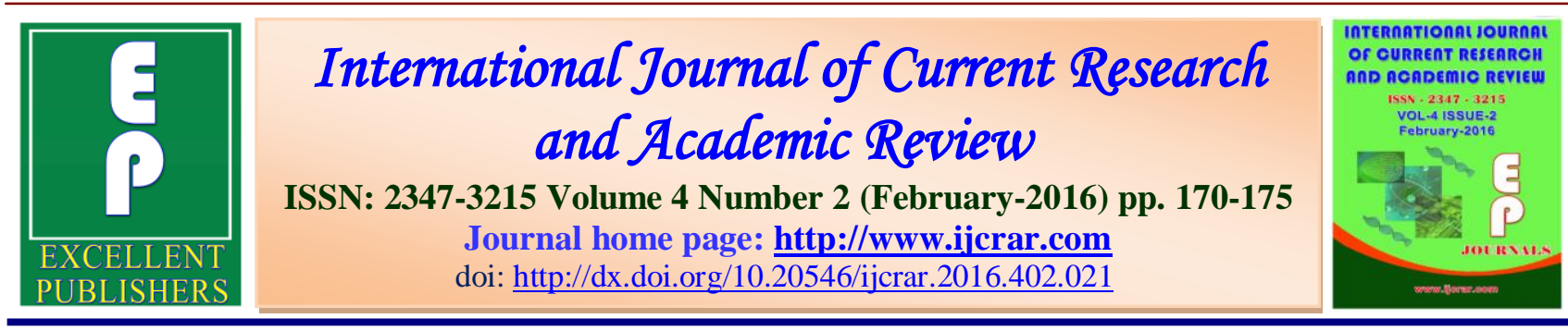

\title{
Molecular Characterization of TEM, SHV and CTX M Genes among ESBL Producing Gram Negative Isolates in ICU
}

\author{
A. Vasumathi ${ }^{1}$, P.R. Thenmozhi Valli $^{2}$, S. Senthamarai ${ }^{2 *}$, C.P. Ramani $^{3}$ and Raja \\ Jagadeesan $^{4}$ \\ ${ }^{1}$ Government Stanley Medical College, Chennai, Tamilnadu, India \\ ${ }^{2}$ Meenakshi Medical College and Research Institute, Enathur, Kanchipuram, Tamilnadu, India \\ ${ }^{3}$ Institute of Microbiology, Madras Medical College, Tamilnadu, India \\ ${ }^{4}$ Senior Assistant professor, King institute, Guindy, Tamilnadu, India
}

\begin{tabular}{|c|c|}
\hline KEYWORDS & $A B S T R A C T$ \\
\hline $\begin{array}{l}\text { ESBL, } \\
\text { TEM, } \\
\text { SHV, } \\
\text { CTX-M }\end{array}$ & $\begin{array}{l}\text { ESBL(extended spectrum } \beta \text { lactamase) producing GNBs are continue to be } \\
\text { the great challenge in clinical setups worldwide. The spread of ESBLs } \\
\text { producing GNB has been rapidly increasing.T EM, SHV \& CTX-M are the } \\
\text { prevalent gene responsible for ESBL production. A total of } 95 \text { gram negative } \\
\text { isolates were isolated from various clinical samples from ICU patients and } \\
\text { subjected for ESBL screening and confirmed by combined disc diffusion } \\
\text { method and MIC tests and } 37 \text { were ESBL producers. These strains were } \\
\text { subjected for molecular analysis TEM, SHV and CTX-M genes. Among the } \\
37 \text { ESBL producers, CTX- M ( } 48.3 \% \text { ) were the predominant gene of isolation } \\
\text { in our study. SHV and TEM were } 41.4 \% \text { and } 17.2 \% \text { respectively. } 68.7 \% \text { of } \\
\text { E.coli \& } 23.1 \% \text { of Klebsiella spp had CTX-M genes, } 92.3 \% \text { of Klebsiella spp } \\
\text { showed SHV genes and } 12.5 \% \text { E.coli \& } 23.1 \% \text { of Klebsiella spp showed } \\
\text { TEM genes. ESBL strains should be confirmed with the molecular analysis to } \\
\text { know the prevalent gene and for epidemiological analysis. }\end{array}$ \\
\hline
\end{tabular}

\section{Introduction}

Antimicrobial resistance is a threat to public health. Among the GNB, extended spectrum beta Lactamase are the major cause of resistance. These enzymes causes lysis of the beta lactam ring which is a serious health concern and implicated in therapeutic failure and complications ESBLs were $1^{\text {st }}$ reported in 1980s, and found out to be point mutations of TEM \& SHV enzymes, which mediates resistance in the beta lactam group of antibiotics. $(1,2,3)$

The mutant of temoneiea (TEM) and sulfhydryl variable (SHV) are the classical ESBLs. The cefotaximase (CTX-M) is another type of beta lactamase which is originated from the environmental genus Kluvera. This hydrolyses cefotaxime and 
ceftriaxone but has very weak action on ceftazidime.(4)

ESBLs are primarily produced by enterobacteriaceae family, in particular Escherichia coli and Klebsiella spp.. These species are playing major role in various types of both hospital and community acquired infections such as bacteremia, CNS infections, Urinary tract infections, respiratory tract infections, wound infections and diarrhoea. $(5,6)$

The aim of the study is to characterize the beta lactam resistant genes (TEM, SHV,CTX-M) in GNB isolated from various clinical samples from ICU patients.

\section{Materials and Methods}

A total of 95 gram negative bacilli were isolated from various clinical samples such as urine, blood, body fluid, sputum, pus, drainage tubes and aspirates, collected from ICU patients from tertiary care hospital, Chennai. All the samples were processed according to standard protocol. Antibiotic susceptibility testing was done by Kirby Bauer disc diffusion method. Isolates showing reduced susceptibility to indicator cephalosporins, ceftriaxone $(30 \mu \mathrm{g})$, ceftazidime $(30 \mu \mathrm{g})$ and cefotaxime $(30 \mu \mathrm{g})$ were further confirmed with combined disc diffusion method. $(7,8,9)$

In vitro susceptibility was determined using double disk synergy test (DDST), as recommended by CLSI guidelines E. coli (ATCC-25922) and K. pneumoniae (ATCC700603) were used as reference strains for quality control of in vitro susceptibility testing.

\section{Double Disc Synergy Test}

(Phenotypic Confirmatory Test) for ESBL:
From the colonies of gram negative bacilli, 0.5 McFarland's turbidity standard suspension was prepared. Lawn culture was made on Muller Hinton Agar plate with this inoculum. Discs of Ceftazidime and Ceftazidime + Clavulanic acid $(30 \mathrm{mcg} / 10$ mcg) were placed aseptically on the surface of MHA. The distance of $15 \mathrm{~mm}$ was kept between the disc and overnight incubation was done at $37^{\circ} \mathrm{C}$. An increase of $\geq 5 \mathrm{~mm}$ in zone diameter of Ceftazidime + Clavulanic acid in comparison to the zone diameter of Ceftazidime alone confirmed the ESBL production by the organisms.(9)

\section{Minimal Inhibitory Concentration (MIC) Agar Dilution Method for ESBL Detection}

Inoculate $1-2 \mu l$ of 4 hours peptone water culture of the isolates were plated on Mueller Hinton Agar plates containing $2 \mu \mathrm{g} / \mathrm{mL}$ to $0.125 \mu \mathrm{g} / \mathrm{mL}$ concentration of serially diluted ceftazidime with and without clavulanic acid. A greater than or equal to 3 fold decrease in MIC for ceftazidimeclavulanic acid versus its MIC when tested alone indicates ESBL positive (CLSI)

\section{Molecular Characterization of Gram Negative ESBL Strains}

Determination of the Genetic Type of $\beta$ Lactamase by Polymerase Chain Reaction (PCR)

A total of 37 phenotypically confirmed (DDST \& MIC), ESBL producing strains were investigated to determine the probable type of $\beta$-lactamase enzyme which was responsible for resistance. Extraction of DNA was performed using DNA extraction kit. PCR amplification of bla genes, including blaTEM, blaSHV and blaCTX-M was performed with Taq master mix DNA polymerase using primers listed in table, 
under the following conditions:Initial denaturation step: $94^{\circ} \mathrm{C}$ for $5 \mathrm{~min}$. 30 cycles consisting of: Denaturation: $94^{\circ} \mathrm{C}$ for $1 \mathrm{~min}$. Annealing: $61^{\circ} \mathrm{C}$ for $1 \mathrm{~min}$.DNA extension: $72^{\circ} \mathrm{C}$ for $1 \mathrm{~min}$. Final extension: $72^{\circ} \mathrm{C}$ for 5 min. Further analysis of the CTX-M enzymes using specific primers listed in table was done to determine the specific group of CTXM under the same conditions. All PCR amplicons were verified by gel electrophoresis on a $2 \%$ agarose gel electrophoresis stained with ethidium bromide $(1 \mu \mathrm{l} / \mathrm{ml})$ for $30 \mathrm{~min}$ under $100 \mathrm{~V}$ in 1X TAE buffer and visualized by ultraviolet transilluminator. PCR amplicon sizes were calculated by a comparison with $100 \mathrm{bp}$ molecular weight DNA ladder. PCR primers for detection of blaTEM, blaSHV and blacTX were blaTEM- $\mathrm{F}$ AAACGCTGGTGAAAGTA, R AGC GATCTGTCTAT -822bp, blaSHV - F ATGCGTTATATTCGCCTGTG, RTGC TTTGTTATTCGGGCCAA- 753 bp and blaCTX-M F CGCTTTGC GATGTGCAG, R ACCGCGATATC GTTGGT- 550 bp ${ }^{(10}$, 11)

\section{Results and Discussion}

Among the 95 isolates of gram negative bacilli, Escherichia coli and Klebsiella spp accounts the predominance of $37.9 \%$ \& $30.5 \%$. Among the $95 \mathrm{GNB}, 49$ were ESBL producer with screening method. Among 49, $38.9 \%$ were found to be ESBL producers by DDST \& MIC test . $43.3 \%$ of E.coli \& $35.1 \%$ of Klebsiella spp were predominant ESBL producers. Urine was the predominant sample of isolation of ESBL producers (51.4).

Globally, patients in the ICUs have encountered an increasing emergence and spread of antibiotic resistant pathogens. Although ICUs generally comprise $5 \%$ of all hospital bed, they account for $20 \%$ to $25 \%$ of all nosocomial infections. The increased risk of infections is associated with the severity of the patient contact with healthcare personal and length of stay in the $\mathrm{ICU}^{(12)}$

Infection and antibiotic resistance are important public health issues and the impact of increased drug resistance are farreaching beyond any doubt. Rise in antibiotic-resistant strains of bacteria is one of the major problem worldwide, mainly in hospitals, and also in the community which has proved difficult to control without effective resources and expenditure.

In our study, (38.9\%) were ESBL producers. The ESBL production varies between $17 \%$ to $70 \%$, reported with various studies ${ }^{.(13,14)}$

By using phenotypic methods for ESBL detection, we can only confirm whether an ESBL is produced or not, but cannot detect the ESBL subtype. Definitive identification is possible only by molecular detection methods which is very essential for the epidemiological analysis. ${ }^{(15)}$

A study by Grover et al. on phenotypic and genotypic methods of ESBL detection concluded PCR to be a reliable method of ESBL detection ${ }^{(16)}$

Among the 37 ESBL producers, CTX- M $(48.3 \%)$ were the predominant gene of isolation in our study. SHV and TEM were $41.4 \%$ and $17.2 \%$ respectively.

$68.7 \%$ of E.coli \& $23.1 \%$ of Klebsiella spp had CTX-M genes, $92.3 \%$ of Klebsiella spp showed SHV genes and $12.5 \%$ E.coli \& $23.1 \%$ of Klebsiella spp showed TEM genes.

In this study conducted in our area, CTX-M was the predominant gene among E.coli, and SHV gene were prevalent in Klebsiella spp. SHV and TEM type ESBLs were dominant 
Int.J.Curr.Res.Aca.Rev.2016; 4(2): 170-175

all over the world in members of the family Enterobacteriaceae during the 1990s, but now appear less important than the widely distributed CTX-M enzymes

Table.1 Distribution of ESBL Producers among the GNB

\begin{tabular}{|l|l|l|l|}
\hline Species & Total number & ESBL producers & Percentage (\%) \\
\hline E.coli & 36 & 16 & 43.3 \\
\hline Klebsiella spp & 29 & 13 & 35.1 \\
\hline Proteus spp & 17 & 4 & 10.8 \\
\hline Pseudomonas aeruginosa & 11 & 4 & 10.8 \\
\hline Acinetobacter spp & 2 & 0 & 0 \\
\hline Total & $\mathbf{9 5}$ & $\mathbf{3 7}$ & $\mathbf{3 8 . 9} \%$ \\
\hline
\end{tabular}

Table.2 Distribution of ESBL and the Specimens

\begin{tabular}{|l|l|l|}
\hline Specimens $(\mathbf{n = 3 7})$ & ESBL producers & Percentage (\%) \\
\hline Urine & 19 & 51.4 \\
\hline Drainage tube tips & 6 & 16.2 \\
\hline Wound swab bronchial & 5 & 13.5 \\
\hline $\begin{array}{l}\text { Trachea } \\
\text { aspirates }\end{array}$ & 3 & 10.8 \\
\hline Blood & 3 & 8.1 \\
\hline
\end{tabular}

Table.3 Distribution of ESBL Genes among the Species

\begin{tabular}{|l|l|l|l|}
\hline Isolates & CTX-M & SHV & TEM \\
\hline E.coli $(\mathrm{n}=16)$ & $11(68.7 \%)$ & - & $2(12.5 \%)$ \\
\hline $\begin{array}{l}\text { Klebsiella } \\
\text { pneumonia }(\mathrm{n}=13)\end{array}$ & $3(23.1 \%)$ & $12(92.3 \%)$ & $3(23.1 \%)$ \\
\hline Total $(\mathbf{n = 2 9})$ & $\mathbf{1 4}(\mathbf{4 8 . 3 \% )}$ & $\mathbf{1 2}(\mathbf{4 1 . 4 \% )}$ & $\mathbf{5 ( 1 7 . 2 \% )}$ \\
\hline
\end{tabular}

$68.7 \%$ of E.coli harboured a CTX-M gene which is followed by TEM (12.5\%) and none had SHV. The predominance of CTX gene in E.coli in our study is correlates with, the study of Vaida et al. ${ }^{(17)}$

In the study of Amany et al, CTX- M was the main type of beta Lactamase, followed by TEM, then SHV. ${ }^{(18)}$ CTX-M gene is the most prevalent ESBL encoding gene found worldwide and now it is replacing TEM and SHV types as the predominant ESBL in many European and Asian countries. (19)
In our study, $92.3 \%$ of Klebsiella pneumoniae had SHV gene, $23.1 \%$ had CTX-M \& $23.1 \%$ had TEM gene. $72 \%$ Klebsiella harboured SHV gene, was reported with the study of Sharma J et al. ${ }^{(15)}$

In a study conducted at Chennai, the bla CTXM to be predominantly isolated in E.coli and Enterobacter species and bla SHV to be predominantly found in Klebsiella and Enterobacter species, which is also concordant with our study.(20) 
CTX-M type $\beta$ lactamases may be the most frequent type of ESBL producing strains worldwide, and they were predominantly found in three geographic areas such as South America, the Far East and Eastern Europe, which has been also reported in China, Japan, India, North America and Western Europe. (21)

ESBL continue to be the major challenge in clinical setups worldwide. The spread of ESBLs producing GNB has been rapidly increasing. This indicates that continuous monitoring system and effective infection control measures absolutely required. ${ }^{(1)}$

\section{Conclusion}

E.coli and Klebsiella spp are the commonest ESBL producers and they were maximum in urine samples. Among the ESBL producers, CTX- $M$ were the predominant gene of isolation followed by SHVand TEM. Infection among ICU patients might be hospital or community acquired and intensive care is a multi-disciplinary team effort lead by the microbiologist and supported as and when required by associated medical \& surgical personnel's. A sustained part the intensivist and the clinical microbiologist are essential for improving patient outcome \& also for resource utilization. The possibility of minimising resistance by controlling the use of antibiotics is a rational approach, but the implementation of effective policies need, a combined approach of appropriate antibiotic use, effective surveillance and good infection control practices is essential to tackle the problem of antibiotic resistance.

\section{References}

1.Saroj Kumar Sah ,Hemalatha S. ESBL mechanisms of antibiotic resistance and epidemiology. Int $\mathbf{J}$ Pharm Tech Research,vol 7,2, 303-309.
2. Fam N., Leflon-Guibout V., Fouad S., Aboul-Fadl L., Marcon E., Desouky D., CTX-M-15-producing Escherichia coli clinical isolates in Cairo (Egypt), including isolates of clonal complex ST10 and clones ST131, ST73, and ST405 in both community and hospital settings, Microb. Drug. Resist., 2011, 17,6773.

3. Meeta Sharma, Sati Pathak, and Preeti Srivastava Prevalence and antibiogram of Extended Spectrum $\beta$-Lactamase (ESBL) producing Gram negative bacilli and further molecular characterization of ESBL producing Escherichia coli and Klebsiella spp.J Clin Diagn Res. 2013 Oct; 7(10): 173-2177.

4. Bonnet R. "Growing group of extendedspectrum $\beta$-lactamases: the CTX-M enzymes," Antimicrobial Agents and Chemotherapy. 2004; 48(1):1-14.

5.Paterson D.L., and Bonomo R.A., Extendedspectrum beta-lactamases clinical update, Clini. Microbiol.Rev., 2005, 18, 4, 657686.

6.Foxman B, the epidemiology of urinary tract infections, Nat Rev Urol. 2010,7,12:653660

7. Mackey and McCartney practical medical microbiology (14 ${ }^{\text {th }}$ edition)

8. Bailey \& Scott's diagnostic microbiology $\left(12^{\text {th }}\right.$ edition). Laboratory methods and strategies for antimicrobials susceptibility testing

9. Clinical and Laboratory Standards Institute. Performance standards for antimicrobial testing, Twenty-First Informational Supplement M100-S21. CLSI, Wayne, Pennsylvania, USA, 2011.

10. Paterson DL, Hujer KM, Hujer AM, Yeiser B, Bonomo MD, Rice LB, Bonomo RA, and the International Klebsiella Study Group: Extendedspectrum $\beta$-lactamases in Klebsiella pneumoniae bloodstream isolates from seven countries: Dominance and widespread prevalence of SHV- and CTX-M-type $\beta$-lactamases. Antimicrob Agents Chemother 2003, 47(11):35543560 . 
11. Hujer KM, Hujer AM, Hulten EA, Bajaksouzian S, Adams J, Donskey CJ, Ecker DJ, Massire C, Eshoo MW, Sampath R, Thomson JM, Rather PN, Craft DW, Fishbain JT, Ewell AJ, Jacobs MR, Paterson DL, Bonomo RA: Analysis of antibiotic resistance genes in multidrug resistant Acinetobacter sp. isolates from military and civilian patients treated at the Walter Reed Army Medical Center. Antimicrob Agents Chemother 2006, 50(12):4114-4123.

12. (Eggimann ,P., Pittet D, Infection control in the ICU, Chest;2001;120:2059-2093.

13. Gopalakrishnan R, Sureshkumar D: Changing Trends in Antimicrobial Susceptibility and Hospital Acquired Infections Over an 8 Year Period in a Tertiary Care Hospital in Relation to Introduction of an Infection Control Programme. J Assoc Physicians India. 2010 December; 58 Suppl: 25-31.

14. Mubarak SA, Abida AE, Hajar MA, Adeel IA. Molecular Characterization and Epidemiology of Extended-Spectrum Beta-Lactamase-Producing Escherichia coli and Klebsiella pneumoniae Isolates in the United Arab Emirates. Med Princ Pract. 2011; 20:177-80.

15. Sharma J, Sharma M \& Ray P: Detection of TEM \& SHV genes in Escherichia coli \& Klebsiella pneumoniae isolates in a tertiary care hospital from India. Indian $J$ Med Res. 2010 September; 132: 332-36.

16 Grover SS, Sharma M, Chattopadhya D, Kapoor H, Pasha ST, Singh G.
Phenotypic and genotypic detection of ESBL mediated cephalosporin resistance in Klebsiella pneumoniae: emergence of high resistance against cefepime, the fourth generation cephalosporin. J Infect 2006; 53(4): 279-88.

17. Vaida S, Marius L, Aurelija B, Justas P, Rita P, Agne G et al., Molecular characterization of extended-spectrum blactamase producing Escherichia coli and Klebsiella pneumoniae isolates from hospitals in Lithuania. Journal of Medical Microbiology. 2010; 59 (10): 1263-65.

18. Amany G. Thabit ,Tharwat R, Elkhannissy, Maggie A, Ibrahim and Adel E Attia. Detection of ESBL production by E.coli urinary pathogens at Assiut University Hospital...

19. Livermore DM, Canton R, Gniadkowski M, Nordmann P, Rossolini GM, Arlet G, et al., CTX-M: changing the face of ESBLs in Europe. $J$ Antimicrob Chemother. 2007 Feb; 59:165-74.

20. Jemima SA, Verghese S. Multiplex PCR for blaCTX-M \& blaSHV in the extended spectrum beta-lactamase (ESBL) producing Gram-negative isolates. Indian J Med Res 2008; 128: 313-7.

21. Asma Al-Jasser M. Extended-Spectrum Beta-Lactamases (ESBLs): A Global Problem. Kuwait Medical Journal. 2006; 38 (3): 171-185.

\section{How to cite this article:}

Vasumathi, A., P.R. Thenmozhi Valli, S. Senthamarai, C.P. Ramani and Raja Jagadeesan. 2016. Molecular Characterization of TEM, SHV and CTX M Genes among ESBL Producing Gram Negative Isolates in ICU. Int.J.Curr.Res.Aca.Rev. 4(2): 170-175.

doi: http://dx.doi.org/10.20546/ijcrar.2016.402.021 